Удк 391-055.1(477.87)“19/20”

DOI https://doi.org/10.15407/nte2021.03.005

\title{
КОЦАН ВАСИАЬ
}

кандидат історичних наук, Аиректор Закарпатського музею народної архітектури та побуту, Аоцент кафеАри археології, етнології та культурології $\mathrm{ABH} 3$ «Ужгородський національний університет». ORCID: http://orcid.org/0000-0003-0644-9725

\section{KOTSAN VASYL}

a Ph.D. in History, a director of the Transcarpathian Museum of Folk Architecture and Customs in Uzhhorod, an associate professor at Archeology, Ethnology and Cultural Studies Department, SHEE Uzhhorod National University. ORCID: http://orcid.org/0000-0003-0644-9725

\section{Бібліографічний опис:}

Коцан, В. (2021) Чоловічий народний оАяг гуцумів Закарпаття XIX - першої половини XX століття. Народна твориість та етнологія, 3 (391), 5-18.

Kotsan, V. (2021) Male Folk Clothes of Transcarpathian Hutsuls in the XIX through to the First Half of the XXth Century. Folk Art and Ethnology, 3 (391), 5-18.

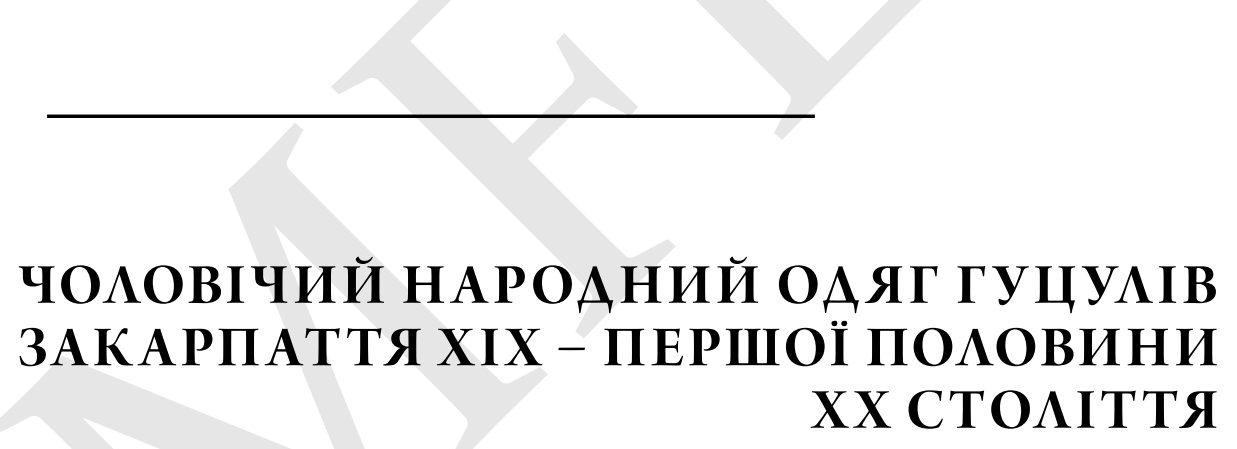

У статті на основі опрацьованої мітератури, архівних та польових етнографічних матеріалів, а також фондових збірок музеїв Закарпаття зАійснено комплексний аналіз складників традиційного народного чоловічого вбрання гуцулів Закарпаття XIX - першої половини XX ст. На Закарпатті гуцули компактно проживали й проживають у межах Рахівського району. За характерними особливостями народного вбрання можна виокремити чотири мокально-територіальні осередки гуцумів Рахівщини: ясінянські, богданські, рахівські та великобичківські. У розвідці детально описано процес крою чоловічих сорочок досліАжуваного регіону: стан сорочок, комірця, рукавів. Особливу увагу приділено оздобленню сорочок вишивкою. Ї̈ еволюція простежується в зміні білих конопмяних ниток чорними, червоними або синіми, а в подальшому - у переході до поліхромності. На чоловічих сорочках переважав геометричний орнамент, а 3 кінця XIX на початку XX ст. починають поширюватися стилізовані рослинні мотиви, що поєАнувалися з геометричними.

Аавніми типами чоловічого поясного одягу гуцумів були червоні сукняні штани, вузькі шкіряні й ткані вовняні пояси. Вони були етнографічно розмежувальною рисою. Суконні червоні штани в межах Закарпаття побутували мише в гуцумів Рахівщини. Їхньою характерною особливістю було озАоблення з'єАнувальних бічних швів декоративними обметувальними смужками темно-оранжевою, зеленою та золотистою ниткою. 3-поміж складників чоловічого вбрання гуцумів Закарпаття вирізнялися головні убори, зокрема весільні капелюхи, які оздоблювали віночками із квітів. На Закарпатті мише в гуцулів Рахівщини побутував виА зимового хутряного головного убору - шлик. Справжнього гуцула не можна також уявити без таких Аоповнювальних елементів народного вбрання, як різноманітні сумки, топірці, Аюльки тощо.

Кмючові смова: народне вбрання, гуцули, Закарпаття, сорочка, штани, пояс, безрукавка, верхній оАяг, головні убори та взуття. 
The author, based on processed literature, archival and field ethnographic materials, as well as fund collections of Transcarpathian museum, conducts, in his article, a comprehensive analysis of components of the traditional male folk clothing of Transcarpathian Hutsuls in the XIXth through to the first half of the XXth century. In Transcarpathia, Hutsuls have lived compactly within Rakhiv District. According to characteristic features of the Hutsuls' national costume, four local-territorial centres of Rakhiv District's Hutsuls can be distinguished: Yasinia, Bohdan, Rakhiv, and Velykyi Bychkiv ones. The paper describes in detail the process of cutting male shirts in the region under study: the condition of shirts, neckbands, and sleeves. The author pays a special attention to embellishing shirts with embroidery. The latter's evolution can be traced in replacing white hemp threads with black, red or blue ones, and later - in the transition to polychromy. Male shirts were dominated by geometric patterns, and since the late XIXth to early XXth centuries, stylized plant motifs combined with geometric ones had begun to spread.

Ancient types of Hutsul male waist clothes were red cloth trousers, as well as narrow leather and woven woolen belts. They were an ethnographically distinguishing trait. Cloth red trousers within Transcarpathia were worn solely by Rakhiv District's Hutsuls. Their distinctive feature was the embellishment of the connecting side seams with decorative whipstitching strips with dark orange, green and goldish threads. Among the components of Transcarpathian Hutsul male attire stood out headdresses, in particular nuptial hats, which were decorated with wreaths of flowers. In Transcarpathia, only the Rakhivshchyna Hutsuls had shlyk - a variety of hibernal fur headdresses. A real Hutsul cannot be imagined as well without such components additional to folk costumes as various bags, axes, and pipes.

Keywords: folk clothing, Hutsuls, Transcarpathia, shirt, trousers, belt, tank top, outerwear, headwear and footwear.

Вступ. Особливості народного оАягу гуцулів Рахівщини скмаАалися піА впливом природно-кміматичних, господарсько-культурних чинників та місцевих побутових траАицій. Народний оАяг карпатських гуцумів протягом століть характеризувався типо-

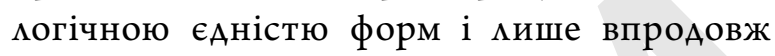
Аругої половини XIX - на початку XX ст. виокремилися його мокамьні ознаки. Саме в ці часи сформувалися Аеякі особливості народного оАягу гуцулів Рахівщини. Гуцули Закарпаття Аімими себе на ясінянських, богАанських, рахівських та вемикобичківських. Ясінянські гуцули пов'язували це з тим, що їні пращури прийшли 3 околиць Косова i Яремчі, богАанські - із с. Верховина (Жаб'є), рахівські - з Галичини і Аолинянських сіл Закарпаття, а вемикобичківських вважами не справжніми гуцумами, а такими, що «погуцумимись» [50, с. 155; 59, с. 30-32]. Такий самоподім певною мірою проявляється в озАобленні й загамьному колориті оАягу названих груп гуцумів Рахівщини. Утім, при цьому в особливостях траАиційної нароАної ноші названих осереАків простежується Аомінування спільних рис.

Аналіз останніх досліджень та публікацій. Основним Ажерелом Аля АосліАження означеної проблематики поскужики помьові етнографічні матеріаци автора, зібрані в експеАиціях та наукових віАрядженнях 2009-
2011 років [1]. Цінною Аля нас $є$ інформація, зАобута піА час комплексних етнографічних експеАицій, організованих викмадачамиісториками УжгороАського націонамьного університету й науковими співробітниками Закарпатського музею народної архітектури та побуту. Практику проведення таких експеАицій було віАновмено в 2015 році. УАітку 2016 року, впродовж трьох тижнів, обстежували понаА Аесять сім в окомицях Великого Бичкова. Результати тодішніх АосліАжень АягАи в основу Аругого випуску наукового щорічника «Етніка Карпат». У низці публікацій, уміщених у ньому, порушувамися й питання про народний оАяг АосліАжуваного регіону [28; 58; 63]. У 2017 році об’єктами АосліАження експеАиції науковців, стуАентів-істориків та музейних співробітників були села Аолини р. Чорна Тиса: Аазещина, Ясіня, Стебний, Чорна Тиса, Бімин та Кваси. За результатами експеАиції вийшов Аруком третій випуск наукового щорічника «Етніка Карпат», у якому опубкіковано інтервю учасників експеАиції про народну обряАовість, зокрема використання народного вбрання в родинній та календарній обрядовості $[51 ; 55]$.

ОАним із головних Ажерел вивчення народного вбрання $є$ музейні збірки. Аля цього АосліАження використано автентичні взірці скмаАників чоловічого вбрання 
гуцуків Рахівщини з фондів Закарпатського музею народної архітектури та побуту, Закарпатського обкасного краєзнавчого музею ім. Тиводара Аегоцького та Музею приклаАного мистецтва Закарпаття при Мукачівському Аержавному університеті.

Аосліджуючи мокальні особливості народного чоловічого оАягу гуцулів Закарпаття, ми використали низку публікацій історичного мистецтвознавчого та краєзнавчого характеру. Певний внесок у вивчення традиційного народного оАягу українців Карпат, у тому числі захіАної частини Закарпаття, зробив Ю. Жаткович (1855-1920) [36, с. 120-122]. Важмивим Ажерелом Аля вивчення нашої проблематики $є$ праці чеських АосліАниць народної культури М. Тумової [61] та А. Кожмінової [66]. На особливу увагу заслуговують досліАження російського мистецтвознавця С. Маковського (1877-1962) [48], науковців радянського періоду О. Командрова [41] та О. Полянської [54].

Із праць сучасних Аослідників народного вбрання варто виокремити пубцікації місцевих істориків, етнографів, краєзнавців і мистецтвознавців М. Тиводара [60] та Р. Пимипа [52; 53]. Вивченню народного оАягу гуцулів Рахівщини присвячено й ряА публікацій автора цієї статті. Скажімо, описові народного вбрання гуцулів Рахівщини присвячено окремі частини його кандиАатської Аисертації [45], а також монографічного АосліАження [44]. Польові етнографічні матеріали, зібрані автором на Рахівщині впродовж багатьох років, надруковано в третьому випуску наукового щорічника «Етніка Карпат» [43]. У 2020 році в німецькому міжнародному журналі «German International Journal of Modern Science» бумо опубліковано статтю про чоловічі сорочки гуцумів Закарпаття [42].

Основна частина. У комплект чоловічого вбрання входили сорочка, полотняні штани («гаті»), сукняні штани («холошні»), шкіряний пояс («римінь»), безрукавний кожушок («кептар»), суконна куртка («сердак»), головні убори, взуття, сумки та топірці.

Головним елементом оАягу гуцула Рахівщини була сорочка («кошуля»). Траплялися чоловічі сорочки трьох видів: стара кошуля (XVIII ст.), нова кошуяя (XIX ст.), фабрична кошуяя (кінець XIX початок XX ст.) [41, с. 87; 54, с. 57; 61, с. 110]. В основі розвитку Авох останніх кежить стара кошуля. Сорочки виготовмяли з прямокутного шматка Аомотканого полотна, зігнутого навпік по ширині. ПосереАині робими круглий виріз горловини й неглибокий розріз пазухи, який зав'язували бікими плетеними шнурками з китичками на кінцях («ощінками»). Ао плечей пришивали прямі широкі рукави. Сорочку по місцях зшивання полотнищ оздоблювали швами відтінками білих ниток. У XVIII - на початку XIX ст. така стара кошуля сягала чоловікам до колін. Ïї носими навипуск, поверх штанів, у поясі перев'язували вовняним поясом («кушаком», «баюром»).

3 перших десятиріч XIX ст. набума поширення нова кошуля. Ї̈ї також шили з Аомотканого полотна. Проте вона, на віАміну віА старої, маха прямий стоячий комір («ошийник»), який зав'язувався «ощінками» або застібувався на гудзики. У XIX ст. сорочки оздоблювали білими, а наприкінці XIX на початку XX ст. - чорними, червоними або синіми швами. Рукави нової сорочки були широкими, цікьнокроєними, з клином («цвікольом»). Святкові сорочки прикрашали пишною вишивкою та Аекоративним швом («штепкою»). Наприкінці XIX ст. в селах Аолини р. Біла Тиса плечики сорочки піАшивали «піАпліччями» $[24 ; 42$, с. 9].

У ясінянських гуцулів нові кошулі кроїли з оАного Аовгого (140-146 см) шматка Аомотканого полотна, зігнутого навпік по ширині. Аовжина сорочок сягака 70-73 см. На переАній частині зігнутого полотнища робили виріз Аля горловини, який переходив у глибокий (15-18 см) розріз («розпірку»). Ао стану сорочки пришивали комір-стійку. По боках Ао стану сорочки, Ао місця встав- 
мення рукавів, пришивали вузькі (10-12 см) пілки-вставки. Рукави нових кошуль довгі (50-55 см) і широкі $[25 ; 15]$.

Характерною особливістю крою довгих (75-80 см) нових кошуль із сік Аолини р. Біка Тиса була ромбоподібна вставка («пуАшитка»), якою підшиваки верхню частину переАньої та заАньої пікок. «Пудшитка» мака запобігати натиранню тіка вишивкою. Більшість богАанських нових кошуль шими 3 Аовгими (45-50 см) широкими цімьнокроєними рукавами, які біля манжет збирали на Аві нитки. Манжети застібували на гуАзики й зав’язвали на плетені шнурочки з китицями на кінцях. ПіА рукавами пришивали невеликі прямокутні вставки («латиці») [21;22].

Нові кошулі рахівських гуцулів за кроєм подібні до богАанських. Їх особливості проявилися в оздобленні вишивкою. У порівнянні з ясінянськими та богданськими, комір, нагрудна частина вздовж розрізу пазухи та манжети рахівських нових кошуль були найширшими. Характерною особливістю манжет було те, що їні краї зрізались у формі трикутників і застібувалися на металеві застібки («капчі») [16].

Фабричні сорочки за кроєм були подібні до нових кошуль, аме мали тенденцію до звуження всіх складових частин. Кроїки іх із Авох пікок, з вузьким (5-8 см) шматком полотна («плечиками»), 3 коміром-стійкою чи віАкиАним коміром («ганіром»). Рукави на сорочках Аовгі (55 см), цільнокроєні, у нижній частині зібрані в широкі (1 см) загинки («защипи»), Ао яких пришивами вузькі (2-3 см) манжети («АуАики»). Фабричні кошулі оАягали, заправляючи в штани $[17 ; 20 ; 23]$.

Гуцулки ставимися Ао пошиття та озАоблення сорочки з великою увагою. Особциво старанно оздоблювали чоловічі сорочки вздовж розрізу пазухи («нагруАника»). Композиція вишивок нагрудників подібна Ао уставкових $[19 ; 38$, с. $83-84 ; 42$, с. $10 ; 43$, c. $204 ; 56$, c. 147$]$.

В оздобленні чоловічих сорочок часто використовували «головкастий взор».
Найпоширенішою модифікацією цього орнаменту на чоловічих сорочках був ромб, сторони якого мали віАростки, а кути завершувалися меншими ромбами із цяткою посереАині. Окреслюючі контури ромба формувалися із чотирьох головкастих мотивів («берегинь») [18].

У кінці XIX - на початку XX ст. у вишивці нагруАників чоловічих сорочок стало Аомінувати поєАнання стилізованих рослинних мотивів 3 геометричними. Центральне місце займав геометричний орнамент, що утворювався за Аопомогою ромбів з усіченими кутами. У вишивці сорочок молодих хлопців та Аівчат Рахівщини поширеним орнаментальним мотивом було серАечко («сирцятко») [44]. Не менш оригінальною і багатою була вишивка на ошийках та манжетах гуцульських чоловічих сорочок. У ній переважами мотиви меандрових міній, «грабельки», «гребінці», «рибки» $[46$, с. 7$]$.

Поясним вбранням гуцулів Рахівського

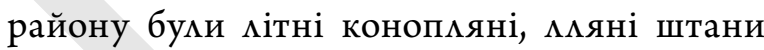
(«гаті», «портки», «портяниці») та зимові сукняні штани («гачі»), «холошні») білого, чорного, синього та червоного кольорів.

Ясінянські гуцули влітку оАягали довгі (90-105 см) штани («портки», «портяниці») з Аомотканого конопцяного чи мАяного полотна. Наприкінці XIX ст. штанини кроїли з оАного прямокутного шматка полотна (90-105×50 cм), зігнутого навпік по ширині, а з 20-х років ХХ ст. - 3 Авох пілок з прямокутним чи кваАратним «кмином» [7; 47, с. 514]. Узимку поверх гатей гуцули оАягали суконні штани («гачі», «холошні», «прічі», «наАраги»). Ясінянські гуцули суконні штани чорного, темно-синього кольорів називали «гаті», а темно-червоні - «гачі», «холошні », «крашаниці ». Червону фарбу Аля фарбування привозики з м. Сигота (Румунія) або із Праги. «Хомошні» робими Аовгими (120-130 см), внизу загортали Ао половини митки. На початку XX ст. повсюАно на Рахівщині піА впливом угорців і румунів поряд 3 «холошнями» 3 Аомотканого сукна поширикися штани («прічі»), пошиті у 
формі галіфе з чорного чи темно-синього фабричного сукна [1].

Сорочку й штани гуцули закріплюва$\Lambda$ и шкіряним поясом. Закарпатські гуцули такий шкіряний пояс «чересом» не називали. Поширеною була назва «римінь». Ïх шили 3 прямокутного шматка шкіри, скмаденого вАвоє й Прошитого Узорними швами. Траплялися пояси Авох видів: прості на защіпці та декоровані («цифровані»). БіАні селяни носили широкий $(20-30$ см) 3 Авома-трьома пряжками. ПереАню частину поясів озАоблювали стилізованими квітами («тюліпанами») та тисненими орнаментальними смугами у вигляді восьми пунктирних міній («штрихівочок») та Арібними кільцями («очками») між ними. Усю зовнішню поверхню «римінів» Аекорували прямими суцікьними мініями («партицями») та «штрихівочками», що послідовно чергувались, а низ - «очками» [14]. Значно ширшими (50-60см), з п'ятьма-шістьма пряжками, були ремені заможних селян. Їх оздоблювали тисненими Узорами, міАними кільцями, Арібними шкіряними гуАзиками («цяточками», «бобриками»), манцюжками («ретязями»), різними за величиною «капслями». Аля щоденного порання по господарству використовували скромніші пояси - вужчі й не так майстерно оздоблені. Вартість оАного «ціфрованого» ременя у 80-х роках XIX ст. Аорівнювала ціні Авох овець. Як прості, так і Аекоровані ремені мали оАне призначення - міцно стягували живіт при важких роботах, захищали нирки віА переохолодження, полегшували хоАіння в горах. На прикріплених до нього гачках носили необхіАні в Аорозі преАмети: скмаАний ніж, огниво, «протичку ААя трубки». За пояс кмали топірець, мюльку, гаманець $[30$, c. $84 ; 51$, c. $275 ; 55$, с. $283 ; 62$, с. 82$]$. Крім широких, на Аві-шість застібок, у гуцуАів побутували й вузькі (4-5 см), на оАну пряжку, ремені («букурія»). Назва «букурія» походить віА румунського «bucurie»«радість». Аовжина таких поясів сягана 100-120 см [35, с. 288]. Наприкінці XIX та на початку XX ст. у гуцулів поширились i ткані вовняні пояси («кушаки»), завдовжки 130-150 см, завширшки 2-5 см. Поясом оАин раз обвивали талію, а потім зав'язували так, щоб кінці спадали набік [5].

Характерним плечовим оАягом гуцулів був кептар - безрукавка на хутрі, оздоблена вишивкою та аплікацією. У способах крою і озАобленні кептарів яскраво проявцяються їхні Аокамьні особливості. На Закарпатській Гуцульщині були віАомі такі назви хутряної безрукавки, як «киптар», «кептар», «киптарь», «кожушок», «кожух», «вішитий кожух», «п'єктар», «п’єхтар», «цифрований п'єктар», «цифрованик» [40, с. 23; 41, с. 84].

Поряа із загальними особливостями в крої та оздобленні кептарів гуцулів Рахівщини проявлялися певні місцеві особливості. Етноідентифікуючою ознакою в оздобленні ясінянських кептарів бума вузька (3-5 см) смужка мисячого хутра («лиси»,

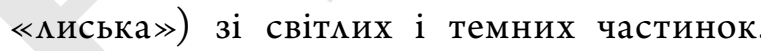

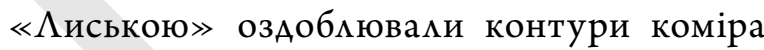
та верхньої частини передніх пілок взАовж розрізу [13; 39, с.77; 65, с. 163]. Кептарі сі Аолини р. Біка Тиса декорували сукняною смужкою вишневого, бордового або малинового кольору. Комір і переАні пілки прикрашали не мисячим хутром, а чорною сукняною тканиною, каракукем або смушком. Ава виАИ озАоблення вирізняємо й У рахівських кептарях. На Рахівщині побутували також мало озАоблені кептарі («киптарі», «піхтаринки») [4; 44, с. 36-37].

Кожухи. Узимку гуцули оАягали кожух 3 рукавами. Шили його з овечих шкір хутром усередину. Кожух прямого крою скмаАався із суцільної заАньої та Авох переАніх пік. Ао верхньої частини стану пришивали широкий (4-6 см) комір-стійку. На переАніх полах - Аві наклалні кишені («жеби»). Рукави були цільнокроєними. Комір, круглий виріз гормовини, поли, поАол, кишені та низ рукавів обшивали смужкою (завширшки 4-6 см) чорного заячого або ягнячого хутра. Застібувався кожух за допомогою полотняних чи шкіряних гудзиків («очок») 
та петель. Верхню частину передніх пілок святкових кожухів ясінянські гуцули озАоблювали шістьма китицями червоного, жовтого та голубого кольорів. На спині на плетеному шнурочку прив'язували ще п'ять-шість китиць («гитиць»). У селах долини р. Біла Тиса та селах Косівська Поляна, Росішка побутували кожухи, які дубили корою вільхи, Ауба й покривали маком, щоб вони става$\Lambda$ и коричневими [13; 32, с. 108].

Куртки. Ще оАним виАом верхнього плечового вбрання гуцулів Рахівщини була куртка, виготовлена $з$ ущільненого домотканого сукна. Сукно на Аеякі куртки фарбили («Аубили») за Аопомогою кори вімьхи, Ауба. Якщо потрібно було, то Аодавали фабричний барвник («скумпію»). У різних місцевостях сукняні куртки називали по-різному. У селах Аолини р. Чорна Тиса куртку темно-коричневого кольору називали «петек», малинового або червоного кольору - «кришиньик». Ао 30-х років ХХ ст. куртку насиченого чорного кольору називали «байбараком». У селах Аолини р. Біка Тиса, у Рахові та навколишніх селах сукняну куртку чорного або коричневого кольору називали «сердак». У захіАних селах Рахівщини (КосівськаПоляна, Росішка) сукняну куртку без оздоблення називали «лийбан», а оздоблені вишивкою - «віші-

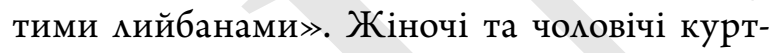
ки відрізнялися мише за розмірами. Чоловічі були на 10-15 см довші за жіночі [29, с. 150]. ЕтноіАентифікуючою ознакою крою гуцульських сердаків були вузькі шматки сукна

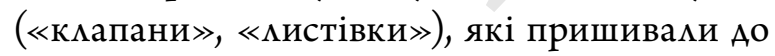
передніх пілок. При оАяганні сердаків «кмапани» накмадали один на оАний. Їх озАоблювали вишивкою, різнокольоровими шнурівками («кісками») та китицями («гитицями»).

Взутmл. Ноги гуцули обвивали в грубі червоні суконні онучі, обшиті по краях жовтим або червоним шнурком («волічкою»). Замість онуч могли взувати плетені з вовняних ниток чи пошиті з червоного сукна шкарпетки («капці»). Поверх онуч чи «капців» оАягали шкіряні постоли, які стягували вовняними шнурками («волоками»)
[30, с. 84]. Чоловічі постоли ні за кроєм, ні за оздобленням не віАрізнялися віА жіночих. Ïх характерною особливістю були гострий, загнутий Аогори, носок та Арібний тиснений чи прорізний орнамент. На початку XX ст. у селах $А$ азещина, Стебний жонаті чоловіки оАягали металеві постоли з дерев'яною піАошвою. Вони були важкими й незручними при ходьбі. Найчастіше їх оАягали місоруби та Аісники.

На початку XX ст. піА впливом міської моАи в гуцулів Рахівщини поширилися шкіряні чоботи. Вони переАавалися віА АіАа Ао внука, позаяк їх пошиття коштувало Аорого. Чоботи були мірилом достатку, що віАбимося навіть у прислів ї: «ВиАно пана по халявах». Чоботи шили зі спеціально обробленої шкіри великої рогатої худоби та овець («юхти»). Чоботи із твердої кінської шкіри називали «кмячовими». У 20-30-х роках $\mathrm{XX}$ ст. чоботи з твердими хамявами почали поступатися м'яким хромовим чоботам 3 тонкої Аубценої шкіри кіз та овець коричневато-жовтуватого кольору. Така шкіра була значно дорожчою за інші, а процес її оброблення - Ауже тривалим.

Заможні гуцули у 20-40-х роках ХХ ст. взували й рамлені («рамовані») чоботи. Вони мали звужену негнучку хамяву, а внизу 6-7 поперечних скмадок («рям»). При ходінні тверда хамява тиснула на «рями» й чоботи виАавали Аивний звук [1].

Зачіски та головні убори. Чоловічі зачіски та головні убори розрізнялися залежно віА пори року та віку. У парубків зачіска була без продіку, а після одруження молоді чоловіки розАіляли волосся на Аві частини. ПіАрізували волосся раз на рік, а щоб воно не заважано при роботі, його змащували жиром і закмадали за вуха.

У гуцулів Рахівщини побутували капемюхи («крисані», «кмебані», «піхлерки») чорного, сірого та зеленого кольорів. Капелюхи молодих парубків мали широку стрічку або вовняну обшнурівку («червачки»), які прикрашали пір'ям сойки, павича («готура»), квіткою еАельвейса, різноманітними «баюр- 
ками», «трясучками» [26]. Збоку обов'язково звисала китиця з круглих волічкових Аармовисів. Аісники за стрічку капелюха кмали шерсть дикого кабана, вилиті з м'якого металу мініатюрні мапки або голівки оленя, козулі, кабана та ін. Спосіб носіння головного убору підкреслював також соціальне становище гуцука. Чим багатший парубок, тим бімьше він зсував капелюх («крисаню») набік, а біАняки повинні були носити його рівно [34, с. 28 ; 43 , с. 204-205; 57, с. 87]. Поширеними були й солом'яні капелюхи («солом'янки»), виготовлені зі стебел жита та ячменю.

Гуцули Рахівщини взимкуодягалиневисокі (14-16 см) шапки («шкики»), виготовлені 3 овчини чорного, сірого або білого кольору. «Шиик» мав загострений верх, який зовні обшивали фабричним сукном темно-синього кольору. Поверх сукна наносили декоративні прошиті стрічки («прошивки») червоного кольору. У верхній частині «шлика» пришиваки китицю із шовкових жовтих, червоних, зелених, рожевих та білих ниток. ПереАня частина «шлика» («чолинець») із Авох боків («крис») облямовувалася чорним ягнячим смушком. СереАина «шиика» була вовняною. У холодну пору криси пускали на вуха [10]. У селах Косівська, Кобилецька Поляна, Росішка побутували чоловічі зимові головні убори («шипка», «дуплашка») 3 овчини, хутром усередину [6].

Аоповнювальні елементи. Наприкінці XIX - на початку XX ст. гуцули Рахівщини на руки оАягали нарукавники («нараквиці») завширшки 10-15 см, плетені або ткані з бікої чи фарбованої овечої вовни, а 320 -х років XX ст. - з гарасових ниток жовтого, зеленого, рожевого та темно-червоного кольору. «Нараквиці» оАягали чоловіки, працюючи в $\Lambda$ ісі в зимовий період [8; 11].

Суттєвим компонентом щоденного і святкового комплектувбрання гуцулів були сумки («бесаги») - подвійні мішки, які гуцули перекидали через плече. Виготовляли їх із довгого полотнища, обидва кінці якого загиналися Аосередини, зшивалися й таким чином утворювали Аві сумки. Використовуваци бесаги
А^я перенесення різних вантажів. Так, пастухи у переАній бесазі переносили їжу та питво Аля себе, а в задній - Аля овець [9].

У середині XIX - першій половині $\mathrm{XX}$ ст. на Рахівщині побутували й звичайні сумки («тайстри»). Шили їх з прямокутного $(120 \times 40 \mathrm{~cm})$ шматка бесагової тканини, зігнутого навпік по ширині та зшитого по боках. Ао верхніх кутів тайстри пришивали Аовгий тканий пояс $з$ різнокольорових вовняних ниток.

На початку XX ст. в гуцулів Рахівщини поширилися святкові сумки («Азьобенки»), За формою вони схожі до тайстр, аме менші за розміром і багатші за декором. Тканини Аля «Азьобенок» подібні до бесагових за композицією, але віАрізняються насиченістю кольорів. При виготовленні «Азьобенок» Ао бокових країв тканини пришивали крайку, а верхню, зовнішню, частину додатково Аекорували металевими гудзиками, вовняними об'ємними китицями («кутасами», «бовтицями») [2].

3начне поширення в Рахівському районі мали чоловічі плоскі шкіряні сумки («табівки») на Аовгому ремені. Їх використовували А^я зберігання та транспортування Арібних

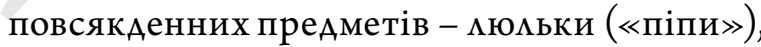
кресала, тютюну. На табівках за допомогою тиснення зображували цілі сюжетні картини: сцени полювання, пейзаж з Авома оленями бікя дерева тощо.

Необхідною належністю чоловічого споряАження гуцулів були Аерев'яні топірці («келефи», «бартки»), які виконували функцію палиці або ручної зброї. Їх оздоблювали розкішною геометричною орнаментикою. Весільні топірці («кмюваки») ясінянських гуцулів декорували кільцями, на кожне з яких прив'язували кольорову стрічечку («ленту»). Ще однією обв'язували цілий «клювак». Із таким топірцем «пані молодий» 3 «пані молодою» йшли запрошувати на весікля [27, c. $37 ; 33$, с. $5 ; 37$, с. $86 ; 64$, с. 15 ].

Висновки. ТраАиційний чоловічий оАяг гуцулів Рахівщини, якщо порівняти із жіночим, є бімьш оАноманітний. Пкечовий без- 
рукавний, верхній оАяг та взуття гуцулів за кроєм і озАобленням подібні Ао жіночого. Відмінність полягала мише в розмірах та насиченості кольорової гами. Головним елементом чоловічого вбрання була сорочка. Протягом XVIII - першої половини XX ст. змінювався її крій, варіанти орнаментальних композицій вишивки, способи оАягання.

Поясним чоловічим вбранням гуцулів Рахівщини були мітні конопляні або мляні штани («гаті», «портки», «портяниці»), зимові сукняні штани («гачі», «холошні», «прічі»), широкі шкіряні пояси («римині»), вузькі «букурії» та ткані вовняні пояси («кушаки»). Гуцула, оАягнутого у вузькі полотняні «гаті», можна було мегко розпізнати між румунами та угорцями, які оАягали широкі короткі полотняні штани («гаті»). Суконні червоні штани («гачі», «холошні», «крашаниці») в межах Закарпаття побутували мише в гуцулів Рахівщини. Їх характерною особливістю було оздоблення з'єАнувацьних швів обметувацьними швами темно-оранжевою, зеленою та золотистою ниткою. Підперезувалися гуцули Рахівщини широкими шкіряними поясами - «рименями» або вузькими «букуріями».

Чоловічі головні убори гуцулів Рахівщини за матеріалом виготовлення поділялися на сукняні (фетрові), солом'яні та хутряні.

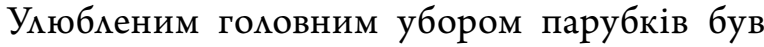
капелюх («крисаня»). Носили його постійно, за винятком холодних місяців року. Етноідентифікуючою ознакою весільних крисань були вінки («вінці пані молодого»), якими озАоблювали («закосичували») один бік капелюха. ОАружені чоловіки носили головні убори з Ауже скромним озАобленням. Зимовий стрій гуцула можна було мегко визначити за зимовим хутряним головним убором («шкиком»). У межах Закарпаття «шлики» побутуваки мише в гуцулів Рахівщини.

Аоповненням Ао чоловічого вбрання скугували різного роду сумки. «Бесаги», «тайстри», «Азьобенки», «тобівки» поряА 3 основною утилітарною функцією були Аоповненням Ао комплексів чоловічого і жіночого оАягу.

\section{Ажерема та мітература}

1. Етноідентифікуючі ознаки та етнографічно-розмежувальні риси народного оАягу гуцулів Рахівщини XIX - першої половини XX ст. Польові матеріали автоpa. Зoшum № 5. 2009-2011 pp.

2. Фонди Комунального закладу «Закарпатський музей народної архітектури та побуту» Закарпатської обласної ради (Аалі - Ф КЗ «3МНАП» 30 Р): 20 . Святкова сумка («Азьобенка»), с. Аазещина, Рахівський р-н. Вовняні нитки, ткання. 20-40-і pp. ХХ ст.

3. Ф К 3 «3МНАП» 3ОР: 301. Шкіряний пояс («римінь») на п’ять пряжок. с. Аазещина, Рахівський р-н. Початок 20-х рр. ХX ст.

4. Ф КЗ «ЗМНАП» 3ОР: 2634/990. Чоловічий кептар («піхтаринка»). с. Ясіня, Рахівський р-н. Овече хутро, чорний ягнячий смушок, вовняні нитки, китиці. Кінець XIX - початок XX ст.

5. Ф К 3 «3МНАП» 3ОР: 2635/991. Тканий чоловічий пояс («кушак»), с. Аазещина. Рахівський р-н. Вовняні нитки, ткання. 20-40-і pp. XX ст.

6. Ф КЗ «3МНАП» 3ОР: 2636/992. Чоловічий зимовий головний убір («Ауплашка»), с. Аазещина, Рахівський р-н. Хутро, фабрична тканина. Початок 30-х pp. XX ст.
7. Ф КЗ «ЗМНАП» 3ОР: 2673/1024. Полотняні штани («портки», «портяниці»), с. Аазещина, Рахівський р-н. Аомоткане полотно, мережка, стряпки. Початок XX ст.

8. Ф КЗ «3МНАП» 3ОР: 3269/1181. Нарукавники («нараквиці»), с. Аазещина, Рахівський р-н. Вовняні нитки, ткання, в'язання. Перша половина XX ст.

9. Ф КЗ «3МНАП» 3ОР: 3413/1447. Бесаги («сакви»), с. Кевемів, Рахівський р-н. Вовняні нитки, ткання. 20-40-і pp. ХХ ст.

10. Ф К 3 «3МНАП» 3ОР: $3417 / 1451$. Чоловіча зимова шапка («шлик»), с. Костилівка, Рахівський р-н. Овече хутро, вовняні нитки. 20-і pp. ХX ст.

11. Ф КЗ «3МНАП» 3ОР: 3426/117. Нарукавники («нараквиці»), с. Розтоки, Рахівський р-н. Вовняні нитки, ткання, в'язання. Перша половина ХХ ст.

12. КЗ «ЗМНАП» 3ОР: 4230/1845. Кожух з рукавами, с. Аазещина, Рахівський р-н. Овече хутро, заячий смушок, вовняні нитки. 20-ті рр. XX ст.

13. Ф КЗ «3МНАП» 3ОР: 4232/1847. Кептар. Ясіня, Рахівський р-н. Овече та мисяче хутро, шкіра, вовняні нитки, мідні бляшки, китиці, аплікація, вишивка. Початок 20-х pp. XX ст. 
14. Ф КЗ «ЗМНАП» 3ОР: 4335/1519. Шкіряний пояс («римінь») на три пряжки. с. Кевелів, Рахівський р-н. Початок XX ст.

15. Ф КЗ «ЗМНАП» 3ОР: 8417/3467. Чоловіча сорочка («нова кошуля»), с. Біли. Рахівський р-н. Аомоткане полотно, вишивка, хрестик. 20-30-ті рр. XX ст.

16. Ф К 3 «ЗМНАП» 3ОР: 9135/3583. Чоловіча сорочка («нова кошуля»), с. Косівська Помяна. Рахівський р-н. Аомоткане полотно, вишивка, хрестик. 30-i pp. XX ст.

17. Ф КЗ «3МНАП» 3ОР: 10126/3908. Чоловіча сорочка («фабрична кошуля»), с. Аазещина, Рахівський р-н. Фабрична матерія, вишивка, хрестик. 30-40-ті рр. XX ст.

18. Ф КЗ «3МНАП» 3ОР: $12527 / 376$. Нагруаник чоловічої сорочки, с. Росішка, Рахівський р-н. Аомоткане полотно, вишивка, низина. Аомінуючий мотив - головкасті мотиви («берегині»). 20-ті рр. ХX ст.

19. Ф КЗ «ЗМНАП» 3ОР: 12632/481. НагруАник чоловічої сорочки, с. Косівська Поляна, Рахівський р-н. Аомоткане полотно, вишивка, низина. Аомінуючий мотив - ромб з Арібноузорною внутрішньою пиощиною. 20-i pp. XX ст.

20. Ф К 3 «3МНАП» 3ОР: $13548 / 288$. Чоловіча сорочка («фабрична кошумя»), с. Ясіня, Рахівський р-н. Фабрична матерія, вишивка, хрестик. 30-40-і pp. XX ст.

21. Ф КЗ «3МНАП» 3ОР: $14536 / 419$. Чоловіча сорочка («нова кошуля»), с. БогАан, Рахівський р-н. Аомоткане полотно, вишивка, хрестик. 20-і рр. ХX ст.

22. Фонди Комунального закладу «Закарпатський обласний краєзнавчий музей ім. ТивоАара Аегоцького» Закарпатської обласної ради (Аалі - Ф КЗ «ЗОКМ» 3ОР) : Е: $387 / 5414$. Чоловіча сорочка («нова кошумя»), с. БогАан, Рахівський р-н. Аомоткане полотно, вишивка, хрестик. 20-і pp. XX ст.

23. Ф К 3 «ЗКМ» 3ОР: 385/5412. Чоловіча сорочка («фабрична кошуля»), с. Костилівка, Рахівський р-н. Фабрична матерія, вишивка, хрестик. 3040-i pp. XX ст.

24. Ф К 3 «3ОКМ» 3ОР: 3844/27148. Чоловіча сорочка («нова кошумя»), с. Аазещина, Рахівський р-н. Аомоткане полотно, вишивка, хрестик. 20-30-і pp. XX ст.

25. Ф КЗ «3ОКМ» 3ОР: 3957/27443. Чоловіча сорочка («нова кошумя»), с. Аазещина, Рахівський р-н. Аомоткане полотно, вишивка, хрестик. 20-30-і рр. ХХ ст.

26. Фонди Музею прикладного мистецтва Закарпаття при Мукачівському Аержавному університеті : 153. Чоловічий капелюх («крисаня»), с. Аазещина, Рахівський р-н. Чорний фетр, зелена фабрична стрічка, паперові квіти, бісер, Азеркальце. 20-40-і рр. ХХ ст.

27. Бачкур Р. Зменшено-пестливі іменники в гуцульських говірках: словотвірна структура. Вісник Прикарпатського національного університету. Філологія. ІваноФранківськ, 2008. Вип. ХIX-XX. С. 36-39.

28. Боршош М. Народне будівництво й оАяг с. Верхнє ВоАяне. Етніка Карпат : науковий щорічник. УжгороА : ВиАавництво Олександри Гаркуші, 2017. Вип. 2. С. 111-116.
29. Ворон А. Підкарпатські гуцули. Подкарпатска Русь. УжгороА, 1931. Рочник VIII. Чис. 7. С. 149-153.

30. Гнатюк В. Гуцули. Подкарпатска Русь. УжгороА 1924. Рочник I. Чис. 3. С. 79-85.

31. Гоберман А. Н. Искусство гуцулов. Москва : Советский художник, 1980. 52 с. : ил.

32. Грибанич I. Народний одяг гуцулів Закарпаття Аругої половини XIX - 50-х рр. XX ст. Науковий збірник Закарпатського краєзнавчого музею. УжгороА : Карпати, 1995. Вип. 1. С. 101-121.

33. Гуцульський гардероб. Місиевий час (Ужгород). 2009. 28 жовтня. С. 5.

34. Гуцумьщина. Наш родный край. Тячево, 1934. Рочник XIII. Чис. 2. С. 27-30.

35. Етимологічний словник української мови : в 7 т. / АН УРСР, Ін-т мовознавства ім. О. О. Потебні : [реАкол. О. С. Мельничук (голов. реА.) та ін. ; укл. : Р. В. Болдирєв та ін.]. Київ : Наукова думка, 1982. Т. 1 : А-Г. 632 с.

36. Жаткович Ю. Етнографическій очерк угро-русских : компиексне виАання / упоряА. і переАм. О. С. Мазурка. УжгороА, 2007. 392 с. : іл.

37. Жолтовський П. М. Орнаментація народних металевих виробів Гуцульщини. Народна творчість та етнографіл. 1958. № 2. С. 75-92.

38. Захарчук-Чугай Р. В. Українська народна вишивка : західні області УРСР. Київ : Наукова думка, 1988. 191 c. : is.

39. Карпинец И. И. Кептари украинского населения Карпат. Карпатский сборник. Труды международной комиссии по изучению народной культуры Карпат и прилегающих к ним областей. Москва : Наука, 1976. С. 75-78.

40. Карпинець I. I. Кептарі Українських Карпат. Аьвів : Видавничий дім «Панорама», 2003. 56. : іл.

41. Команаров О. Ф. Народний костюм Рахівщини. Народна творчість та етнографія. 1959. № 3. С. 82-88.

42. Коцан В. Сорочка - головна складова чоловічого народного вбрання гуцулів Закарпаття кінця XIX - першої половини XX ст. Deutsche internationale Zeitschrift für zeitgenössische Wissenschaft / German International Journal of Modern Science. 2020. № 3. Vol. 1. S. 8-12.

43. Коцан В. Традиційний народний оАяг гуцулів Рахівщини (з польових етнографічних матеріалів). Етніка Kарпат : науковий щорічник. УжгороА : ВиАавництво Олександри Гаркуші, 2018. Вип. 3. С. 195-215.

44. Коцан В. Традиційний народний оАяг гуцумів Рахівщини : XIX - перша половина XX ст. УжгороА : Видавництво Олександри Гаркуші, 2012. 164 с. : іл.

45. Коцан В. Традиційний народний оАяг як прояв іАентичності етнографічних груп українців Закарпаття (XIX - першої половини XX ст.) : Аис. канА. істор. наук : спец. 07.00.05 - «Етнологія». УжгороА : ABHЗ $\ll \mathrm{У}_{ж Н У} \gg, 2013.412 \mathrm{c}$.

46. Коцур Н. М. I на тім рушникові : метоА. посібник. Аонецьк, 2007. 34 с.

47. Кутельмах К. Календарна обрядовість як етногенетичне Ажерело. Етногенез та етнічна історія населен- 
ня Українських Kарпат : у 4 m. T. 2. Етнологія та мистецтвознавство / гол. ред. С. П. Павлюк. Аьвів : Афіша, 2006. C. 473-557.

48. Маковский С. К. Народное искусство Подкарпатской Руси. Прага : Пиамя, 1925. 156 с. : ил.

49. Никорак О. I. Сучасні художні тканини Українських Карпат. Київ : Наукова Аумка, 1988. 224 с.

50. Олексюк Я. Генетичне коріння гуцульського строю: єАність матеріального і Ауховного. Вісник Прикарпатського університету. Мистецтвознавство. ІваноФранківськ, 2009-2010. Вип. 17-18. С. 154-159.

51. Павлюх В. Традиційна народна обрядовість села Стебний. Етніка Kарпат : науковий щорічник. УжгороА : Видавництво Олександри Гаркуші, 2018. Вип. 3. С. 270-278.

52. Пилип Р. І. Художня вишивка українців Закарпаття XIX - першої половини XX ст. (типологія за призначенням, художніми та Аокальними особливостями) : Аис. канА. мистецтвознавства : спец. 17.00.06. «Аекоративне і приклаАне мистецтво». Аьвів, 2009. 269 с., іц.

53. Пилип Р. І. Художня вишивка українців Закарпаття XIX - першої половини XX ст. (типологія за призначенням, художніми та локальними особливостями). УжгороА : ПП «Повч Р. М.», 2012. 466 с.

54. Полянская Е. В. Народная одежАа гуцуяов Раховского района. Карпатский сборник. Труды международной комиссии по изучению народной культуры Карпат и прилегающих к ним областей. Москва : Наука, 1972. С. 57-65.

55. Понзель С. Весільна обрядовість ясінянських гуцумів. Етніка Карпат : науковий щорічник. УжгороА : ВиАавництво Олександри Гаркуші, 2018. Вип. 3. С. 279-283.

56 . Семчук $\Lambda$. Розташування вишивок на компонентах оАягу етнографічних груп українців Карпатського регіону: порівняльний аспект. Вісник Прикарпатського університету. Мистецтвознавство. Івано-Франківськ, 2009-2010. Вип. 17-18. С. 144-154.

57. Стельмащук Г. Г. Традиційні головні убори українів. Київ : Наукова думка, 1993. 240 с.

58. Студзинська Р. Народне житло й оАяг Великого Бичкова. Етніка Карпат: науковий щорічник. УжгороА : ВиАавництво Олександри Гаркуші, 2017. Вип. 2. С. 117-121.

59. Тиводар М. П. Етнографічне районування українців Закарпаття (за матеріалами традиційної культури Аругої половини XIX - першої половини XX ст.). Carpatica. Kaрпатика. Bип. 6. Етнічні та історичні традиції населення Українських Карпат кіния XVIII-XX cm. УжгороА, 1999. Вип. 6. С. 4-64.

60. Тиводар М. П. Етнографія Закарпаття : історикоетнографічний нарис. УжгороА : ГражАа, 2011.416 с. : іА

61. Тумова М. Народная одежа на Подкарпатской̆ Руси. Подкарпатска Русь. УжгороА, 1924. Рочник I. Чис. 4. С. 102-110.

62. ФеАака П. М. Краса народного вбрання. Пам'ять рідної землі. Ужгород : Закарпат краєзнав. музей, Закарпат. крайове т-во «Просвіта», 1996. С. 77-88.

63. Ференц М. Особливості весімля с. Росішка. Етніка Kарпат : науковий щорічник. УжгороА : Видавництво Олександри Гаркуші, 2017. Вип. 2. С. 56-62.

64. Хоткевич Г. Гуцули і Гуцумьщина. Нью-Йорк : Свобода, 1920.32 с.

65. Чіх-Книш Б. Аокальні художні особливості гуцульських кептарів. Вісник Прикарпатського університеmу. Мистецтвознавство. Івано-Франківськ : Пиай, 2003. Вип. 5. С. 162-169.

66. Kožminová A. Podkarpatska Rus. Práce a život lidu po stránce kulturní, hospodářské a národopisné. Praha, 1922. $124 \mathrm{~s}$.

\section{References}

1. Authorial Field Materials. Notebook no. 5 (20092011): Ethno-Identifying Features and Ethnographically Distinguishing Traits of the Rakhivshchyna Hutsul Folk Clothes in the XIXth through to the First Half of the XXth Century [in Ukrainian].

2. Transcarpathian Regional Council's Public Institution Transcarpathian Museum of Folk Architecture and Customs in Uzhhorod Funds (hereinafter - TRC PI TMFACU F): 20. A festive bag (dziobenka), Lazeshchyna village (Rakhiv District). Woollen fibre, weaving, 1920s1940s [in Ukrainian].

3. TRC PI TMFACU F: 301. A fivebuckle leather belt (rymin), Lazeshchyna village (Rakhiv District). The early 1920s [in Ukrainian].

4. TRC PI TMFACU F: 2634/990. A male keptar (short sleeveless fur coat) (pikhtarynka), Yasinia village (Rakhiv District). Sheep fur, black lambskin, woollen fibre, tassels. The late XIXth - early XXth centuries [in Ukrainian].
5. TRC PI TMFACU F: 2635/991. A woven male belt (kushak), Lazeshchyna village (Rakhiv District). Woollen fibre, weaving, 1920s-1940s [in Ukrainian].

6. TRC PI TMFACU F: 2636/992. A male hibernal headdress (duplashka), Lazeshchyna village (Rakhiv District). Fur, manufacturing fabric, early 1930s [in Ukrainian].

7. TRC PI TMFACU F: $2673 / 1024$. Linen trousers (portky, portianytsi), Lazeshchyna village (Rakhiv District). Home-woven fabric, merezhka, striapky, early XXth century [in Ukrainian].

8. TRC PI TMFACU F: 3269/1181. Oversleeves (narakvytsi), Lazeshchyna village (Rakhiv District). Woollen fibre, weaving, knitting. The first half of the XXth century [in Ukrainian].

9. TRC PI TMFACU F: 3413/1447. Besahy (sakvy (shoulder bag), Keveliv village (Rakhiv District). Woollen fibre, weaving, 1920s-1940s [in Ukrainian]. 


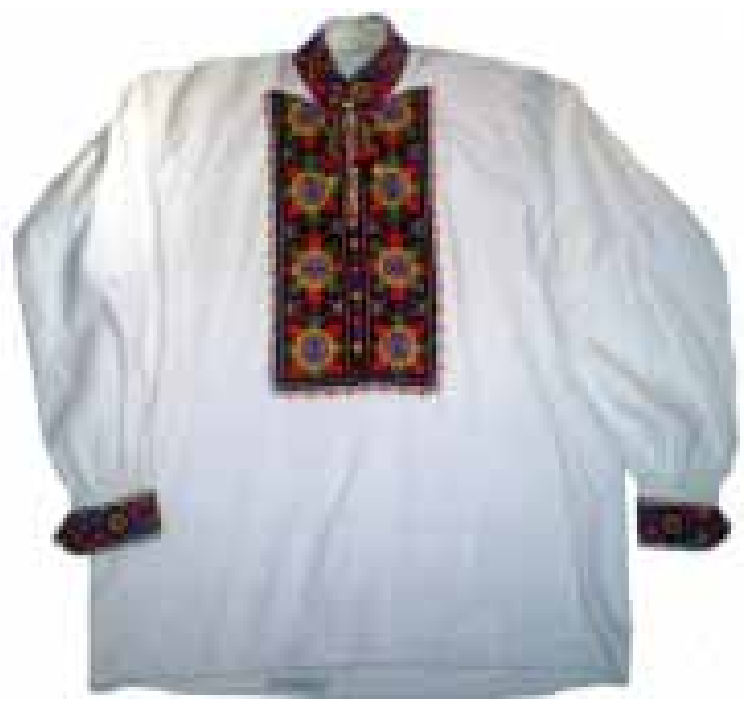

Чоловіча сорочка («нова кошуля»). с. Косівська Поляна Рахівського р-ну. Домоткане полотно, вишивка, хрестик. 30-ті рр. XX ст.

(Ф КЗ «ЗМНАП» ЗОР: 9135/3583)

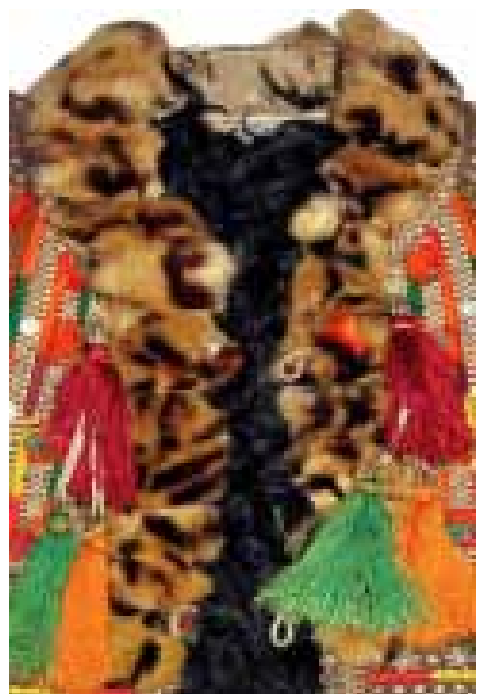

Вузька смушка лисячого хутра («лиси», «лиська») на чоловічій хутряній безрукавці («кептарі»). с. Лазещина Рахівського $\mathrm{p}$-ну. Початок XX ст. (Ф КЗ «ЗМНАП» 3OP: 110/97)

Шкіряний пояс («римінь»). с. Ясіня Рахівського р-ну. 20-ті рр. XX ст. Фото з архіву В. Коцана

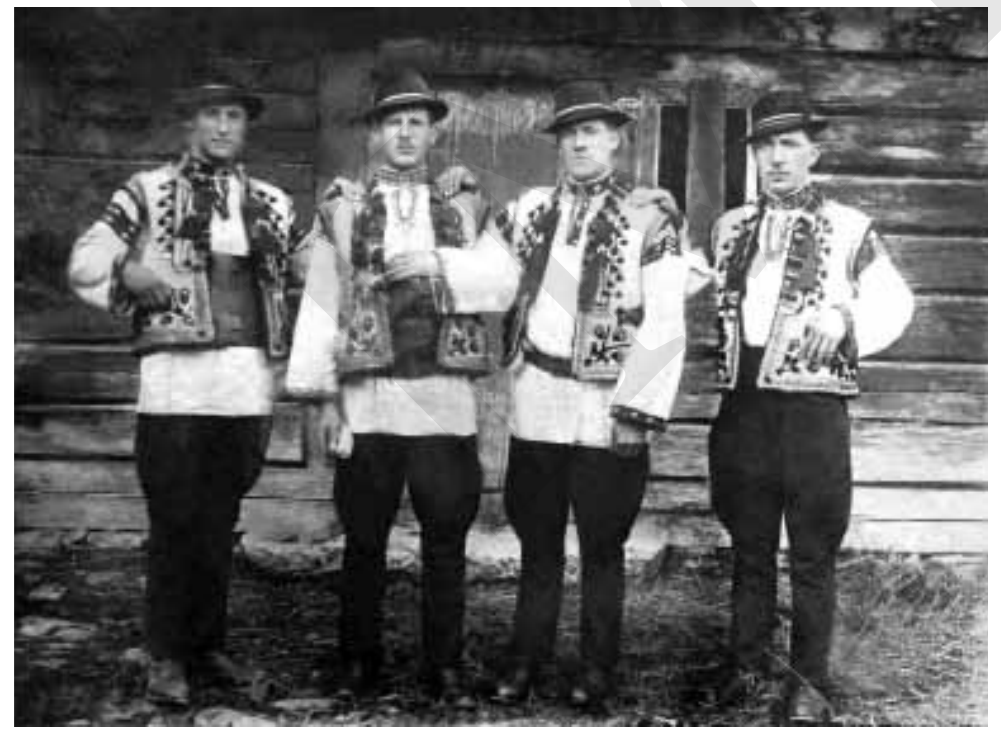

Хлопці («легіні»).

с. Ясіня Рахівського р-ну. 30-ті рр. XX ст. Фото 3 архіву Е. Зелінського

Гуцули із с. Ясіня Рахівського р-ну. 1935 р. Фото з архіву Е. Зелінського.

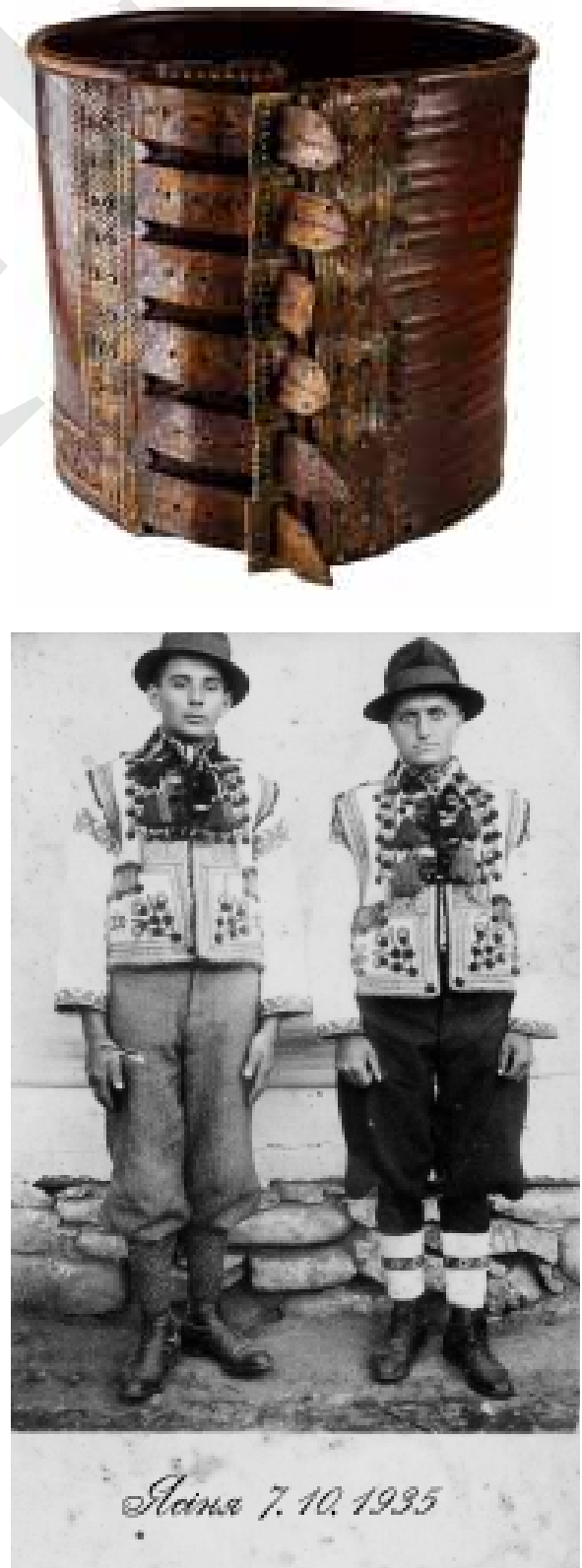


10. TRC PI TMFACU F: 3417/1451. A male hibernal hat (shlyk), Kostylivka village (Rakhiv District). Sheep fur, woollen fibre, 1920s [in Ukrainian].

11. TRC PI TMFACU F: 3426/117. Oversleeves (narakvytsi), Roztoky village (Rakhiv District). Woollen fibre, weaving, knitting. The first half of the XXth century [in Ukrainian].

12. TRC PI TMFACU F: 4230/1845. A sleeved sheepskin coat, Lazeshchyna village (Rakhiv District). Sheep fur, hare fur, woollen fibre, 1920s [in Ukrainian].

13. TRC PI TMFACU F: 4232/1847. A female keptar (short sleeveless fur coat), Yasinia village (Rakhiv District). Sheep fur and fox-fur, leather, woollen fibre, copper plates, tassels, applique, embroidery, early 1920s [in Ukrainian].

14. TRC PI TMFACU F: $4335 / 1519$. A fivebuckle leather belt (rymin), Keveliv village (Rakhiv District). The early XXth century [in Ukrainian].

15. TRC PI TMFACU F: 8417/3467. A male shirt (nova koshulia), Bilyn village (Rakhiv District). Home-woven fabric, embroidery, cross-stitch, 1920s-1930s [in Ukrainian].

16. TRC PI TMFACU F: $9135 / 3583$. A male shirt (nova koshulia), Kosivska Poliana village (Rakhiv District). Home-woven fabric, embroidery, cross-stitch, 1930s [in Ukrainian].

17. TRC PI TMFACU F: $10126 / 3908$. A male shirt (fabrychna koshulia), Lazeshchyna village (Rakhiv District). Manufacturing fabric, embroidery, cross-stitch, 1930s-1940s [in Ukrainian].

18. TRC PI TMFACU F: $12527 / 376$. A male shirt's bib, Rosishka village (Rakhiv District). Home-woven fabric, embroidery, wrong-side running stitch. The dominant motif is head-shaped ones (Berehynias), 1920s [in Ukrainian].

19. TRC PI TMFACU F: 12632/481. A male shirt's bib, Kosivska Poliana village (Rakhiv District). Homewoven fabric, embroidery, wrong-side running stitch. The dominant motif is a rhombus with a finely patterned inner plane, 1920s [in Ukrainian].

20. TRC PI TMFACU F: $13548 / 288$. A male shirt ( $f a b$ rychna koshulia), Yasinia village (Rakhiv District). Manufacturing fabric, embroidery, cross-stitch, 1930s-1940s [in Ukrainian].

21. TRC PI TMFACUF: $14536 / 419$. A male shirt (nova koshulia), Bohdan village (Rakhiv District). Home-woven fabric, embroidery, cross-stitch, 1920s [in Ukrainian].

22. Transcarpathian Regional Council's Public Institution Lehoczky Tivadar Transcarpathian Regional Museum of Local History Funds (hereinafter - TRC PI LTTRMLH F): E: 387/5414. A male shirt (nova koshulia), Bohdan village (Rakhiv District). Home-woven fabric, embroidery, cross-stitch, 1920s [in Ukrainian].

23. TRC PI LTTRMLH F: 385/5412. A male shirt (fabrychna koshulia), Kostylivka village (Rakhiv District). Manufacturing fabric, embroidery, cross-stitch, 1930s1940s [in Ukrainian].
24. TRC PI LTTRMLH F: 3844/27148. A male shirt (nova koshulia), Lazeshchyna village (Rakhiv District). Home-woven fabric, embroidery, cross-stitch, 1920s1930s [in Ukrainian].

25. TRC PI LTTRMLH F: 3957/27443. A male shirt (nova koshulia), Lazeshchyna village (Rakhiv District). Home-woven fabric, embroidery, cross-stitch, 1920s1930s [in Ukrainian].

26. Mukachevo State University's Museum of Applied Arts of Transcarpathia Funds: 153. A male hat (krysania), Lazeshchyna village (Rakhiv District). Black felt, green factory ribbon, paper flowers, beads, and a small mirror, 1920s-1940s [in Ukrainian].

27. BACHKUR, Roman. Diminutive Nouns in Hutsul Dialects: A Derivational Structure. In: Vasyl GRESHCHUK (editorial board's chair), Volodymyr MATVIYISHYN (editorial staff's chairperson). Bulletin of the Precarpathian University. Philology (Linguistics) Series. Chair of Ukrainian Language of the Institute of Philology (Vasyl Stefanyk Precarpathian National University). IvanoFrankivsk, 2008, iss. XIX-XX, pp. 36-39 [in Ukrainian].

28. BORSOS, Mariana. Folk Construction and Clothes of the Village of Verkhnie Vodiane. In: Vasyl KOTSAN and Pavlo LENIO (compilers). Ethnic Life of the Carpathians: A Scientific Yearly: Articles and Materials of Ethnographic Expeditions. Transcarpathian Regional Council's Public Institution Transcarpathian Museum of Folk Architecture and Customs in Uzhhorod, SHEE Uzhhorod National University's Department of Archeology, Ethnology and Cultural Studies. Uzhhorod: Oleksandra Harkusha Publishing House, 2017, iss. 2, pp. 111-116 [in Ukrainian].

29. VORON, Andriy. Subcarpathian Hutsuls. In: Subcarpathian Rus. Uzhhorod: Pedagogical Society of Subcarpathian Rus, 1931, yr. VIII, no. 7, pp. 149-153 [in Ukrainian].

30. HNATIUK, Volodymyr. Hutsuls. In: Subcarpathian Rus. Uzhhorod: Pedagogical Society of Subcarpathian Rus, 1924, yr. I, no. 3, pp. 79-85 [in Ukrainian].

31. GOBERMAN, David. The Art of the Hutsuls. Moscow: Soviet Artist, 1980, 52 pp., ill. [in Russian].

32. HRYBANYCH, Ilya. Folk Clothes of Transcarpathian Hutsuls in the Latter Half of the XIXth to the 1950s. In: Pavlo FEDAKA (compiler and scientific editor). Scientific Collection of the Transcarpathian Museum of Local History. Uzhhorod: Carpathians, 1995, iss. I, pp. 101121 [in Ukrainian].

33. ANON. Hutsul Wardrobe. In: Viktor SHCHADEY, ed.inchief, Local Time. Uzhhorod, 2009, October 28, p. 5 [in Ukrainian].

34. ANON. Hutsulhchyna. In: Our Native Land. Tiachiv, 1934, yr. XIII, no. 2, pp. 27-30 [in Ukrainian].

35. MELNYCHUK, Oleksandr (editorial board's chair). An Etymological Dictionary of the Ukrainian Language: in Seven Volumes. Compiled by Rostyslav BOLDYRIEV et al. UkrSSR Academy of Sciences' Oleksandr Potebnia Institute of Linguistics. Kyiv: Scientific Thought, 1982, vol. 1: $(A-\Gamma), 632$ pp. [in Ukrainian]. 
36. ZHATKOVYCH, Yuriy-Kálmán. An Ethnographic Essay on the Hungarian Ruthenians: A Comprehensive Edition. Compiled and prefaced by Oleh Mazurok. Uzhhorod: Artistic Line, 2007, 392 pp., ill. [in Ukrainian].

37. ZHOLTOVSKYI, Pavlo. Ornamentation of the Hutsulshchyna Folk Metalware. In: Maksym RYLSKYI, ed.inchief, Folk Art and Ethnography. 1958, no. 2, pp. 75-92 [in Ukrainian].

38. ZAKHARCHUK-CHUHAY, Rayisa. The Ukrainian Folk Embroidery: Western Regions of the USSR: A Monograph. AS of Ukraine's M. Rylskyi IASFE, Lviv Branch. Kyiv: Scientific Thought, 1988, 191 pp., ill. [in Ukrainian].

39. KARPINETS, Irina-Iziaslava. Keptari of the Ukrainian Population of the Carpathians. In: Yulian BROMLEY, ed., The Carpathian Collection: Proceedings of the International Commission for Studying the Folk Culture of the Carpathians and Adjacent Areas. Nicholas MiklouhoMaclay Institute of Ethnography, USSR Academy of Sciences. Moscow: Science, 1976, pp. 75-78 [in Russian].

40. KARPYNETS, Iryna-Iziaslava. Keptari of the Ukrainian Carpathians. Lviv: Panorama Publishing House, 2003, 56 pp., ill. [in Ukrainian].

41. KOMANDROV, Oleksandr. The Rakhivshchyna Folk Attire. In: Maksym RYLSKYI, ed.inchief, Folk Art and Ethnography, 1959, no. 3, pp. 82-88 [in Ukrainian].

42. KOTSAN, Vasyl. Shirts as a Main Component of Male Folk Attire of the Transcarpathian Hutsuls in the Late XIXth through the First Half of the XXth Century. In: Reinhardt ROTH, ed.inchief, Deutsche internationale Zeitschrift für zeitgenössische Wissenschaft / German International Journal of Modern Science, 2020, no. 3, vol. 1, pp. 8-12 [in Ukrainian].

43. KOTSAN, Vasyl. Traditional Folk Clothes of the Rakhivshchyna Hutsuls (From Field Ethnographic Materials). In: Vasyl KOTSAN and Pavlo LENIO (compilers). Ethnic Life of the Carpathians: A Scientific Yearly: Articles and Materials of Ethnographic Expeditions. Transcarpathian Regional Council's Public Institution Transcarpathian Museum of Folk Architecture and Customs in Uzhhorod, SHEE Uzhhorod National University's Department of Archeology, Ethnology and Cultural Studies. Uzhhorod: Oleksandra Harkusha Publishing House, 2018, iss. 3, pp. 195-215 [in Ukrainian].

44. KOTSAN, Vasyl. Traditional Folk Clothes of the Rakhivshchyna Hutsuls (XIXth to the First Half of the XXth Century). Uzhhorod: Oleksandra Harkusha Publishing House, 2012, 164 pp., ill. [in Ukrainian].

45. KOTSAN, Vasyl. Traditional Folk Clothes as a Manifestation of Identity of Ethnographic Groups of Transcarpathian Ukrainians (XIXth to the First Half of the XXth Century). Ph.D. in History thesis: 07.00.05 (Ethnology). NAS of Ukraine, I. Krypyakevych Institute of Ukrainian Studies (Lviv), Institute of Ethnology. Uzhhorod: Uzhhorod National University, 2013, 412 pp. [in Ukrainian].

46. KOTSUR, Natalia. And on that Towel: A Methodical Manual. Donetsk, 2007, 34 pp. [in Ukrainian].
47. KUTELMAKH, Korneliy. Calendar Rituals as an Ethnogenetic Source. In: Stepan PAVLIUK, ed.inchief, Ethnogenesis and Ethnic History of the Ukrainian Carpathians' Population: in Four Volumes. NAS of Ukraine's Institute of Ethnology. Lviv: Afisha, 2006, Vol. 2: Ethnology and Art Studies, pp. 473-557 [in Ukrainian].

48. MAKOVSKIY, Sergey. Folk Art of Subcarpathian Rus. Prague: Flame, 1925, 156 pp., ill. [in Russian].

49. NYKORAK, Olena. Modern Artistic Textiles of the Ukrainian Carpathians. AS of Ukraine's M. Rylskyi IASFE, Lviv Branch. Kyiv: Scientific Thought, 1988, 224 pp. [in Ukrainian].

50. OLEKSIUK, Yaroslava. Genetic Roots of the Hutsul Outfit: Unity of the Material and Spiritual. In: Vasyl GRESHCHUK (editorial board's chair), Mykhaylo STANKEVYCH (editorial staff's chairperson). Bulletin of the Precarpathian University. Art Studies Series. Institute of Arts of the Vasyl Stefanyk Precarpathian National University. Ivano-Frankivsk: Vasyl Stefanyk Precarpathian National University, 2009-2010, iss. XVII-XVIII: On the Occasion of the 70th Anniversary of Establishing the Vasyl Stefanyk Precarpathian National University, pp. 154-159 [in Ukrainian].

51. PAVLIUKH, Volodymyr. Traditional Folk Rites of the Village of Stebnyi. In: Vasyl KOTSAN and Pavlo LENIO (compilers). Ethnic Life of the Carpathians: A Scientific Yearly: Articles and Materials of Ethnographic Expeditions. Transcarpathian Regional Council's Public Institution Transcarpathian Museum of Folk Architecture and Customs in Uzhhorod, SHEE Uzhhorod National University's Department of Archeology, Ethnology and Cultural Studies. Uzhhorod: Oleksandra Harkusha Publishing House, 2018, iss. 3, pp. 270-278 [in Ukrainian].

52. PYLYP, Roman. The Art of Embroidery of Ukrainian Transcarpathia in the XIXth through the First Half of the XXth Century (Functional Typology, Artistic and Local Features). Ph.D. in Art Criticism thesis. Specialty: 17.00.06 (Decorative and Applied Art). Lviv National Academy of Arts. Lviv, 2009, 269 pp., ill. [in Ukrainian].

53. PYLYP, Roman. The Art of Embroidery of Ukrainian Transcarpathia in the XIXth through the First Half of the XXth Century (Functional Typology, Artistic and Local Features). Uzhhorod: PE Povch R. M., 2012, 466 pp. [in Ukrainian].

54. POLIANSKAYA, Elena. Folk Clothes of Rakhiv District's Hutsuls. In: Yulian BROMLEY, ed., The Carpathian Collection: Proceedings of the International Commission for Studying the Folk Culture of the Carpathians and Adjacent Areas. Nicholas Miklouho-Maclay Institute of Ethnography, USSR Academy of Sciences. Moscow: Science, 1972, pp. 57-65 [in Russian].

55. PONZEL, Serhiy. Nuptial Ceremonies of the Village of Yasinia's Hutsuls. In: Vasyl KOTSAN and Pavlo LENIO (compilers). Ethnic Life of the Carpathians: A Scientific Yearly: Articles and Materials of Ethnographic Expeditions. Transcarpathian Regional Council's Public 
Institution Transcarpathian Museum of Folk Architecture and Customs in Uzhhorod, SHEE Uzhhorod National University's Department of Archeology, Ethnology and Cultural Studies. Uzhhorod: Oleksandra Harkusha Publishing House, 2018, iss. 3, pp. 279-283 [in Ukrainian].

56. SEMCHUK, Lesia. Location of Embroideries on Components of Clothes of Ethnographic Groups of the Carpathian Ukrainians: A Comparative Aspect. In: Vasyl GRESHCHUK (editorial board's chair), Mykhaylo STANKEVYCH (editorial staff's chairperson). Bulletin of the Precarpathian University. Art Studies Series. Institute of Arts of the Vasyl Stefanyk Precarpathian National University. Ivano-Frankivsk: Vasyl Stefanyk Precarpathian National University, 2009-2010, iss. XVII-XVIII: On the Occasion of the 70th Anniversary of Establishing the Vasyl Stefanyk Precarpathian National University, pp. 144-154 [in Ukrainian].

57. STELMASHCHUK, Halyna. Traditional Headgear of the Ukrainians. Kyiv: Scientific Thought, 1993, 240 pp. [in Ukrainian].

58. STUDZYNSKA, Romana. Folk Abodes and Clothes of the Urban-Type Settlement of Velykyi Bychkiv. In: Vasyl KOTSAN and Pavlo LENIO (compilers). Ethnic Life of the Carpathians: A Scientific Yearly: Articles and Materials of Ethnographic Expeditions. Transcarpathian Regional Council's Public Institution Transcarpathian Museum of Folk Architecture and Customs in Uzhhorod, SHEE Uzhhorod National University's Department of Archeology, Ethnology and Cultural Studies. Uzhhorod: Oleksandra Harkusha Publishing House, 2017, iss. 2, pp. 117-121 [in Ukrainian].

59. TYVODAR, Mykhaylo. Ethnographic Zoning of Transcarpathian Ukrainians (Based on the Materials of Their Traditional Culture in the Latter Part of the XIXth through to the First Half of the XXth Century). In: Vyacheslav KOTYHOROSHKO and Mykhaylo TYVODAR, eds.inchief, Carpatica. SHEE Uzhhorod National University and Research Institute of Carpath- ian Studies (Uzhhorod National University). Uzhhorod, 1999, iss. 6: Ethnic and Historical Traditions of the Ukrainian Carpathians' Population in the Late XVIIIth through the XXth Century, pp. 4-64 [in Ukrainian].

60. TYVODAR, Mykhaylo. Ethnography of Transcarpathia: A Historical and Ethnographic Essay. Uzhhorod: Grajdă, 2011, 416 pp., ill. [in Ukrainian].

61. TŮMOVÁ, Marie. Folk Clothes in Subcarpathian Rus. In: Subcarpathian Rus. Uzhhorod: Pedagogical Society of Subcarpathian Rus, 1924, yr. I, no. 4, pp. 102-110 [in Russian].

62. FEDAKA, Pavlo. Beauty of Folk Costumes. In: Pavlo FEDAKA. Memory of the Native Land. Transcarpathian Museum of Local History, Transcarpathian Regional Society Prosvita. Uzhhorod, 1996, pp. 77-88 [in Ukrainian].

63. FERENC, Miroslava. Features of Wedding Ceremony in the Village of Rosishka. In: Vasyl KOTSAN and Pavlo LENIO (compilers). Ethnic Life of the Carpathians: A Scientific Yearly: Articles and Materials of Ethnographic Expeditions. Transcarpathian Regional Council's Public Institution Transcarpathian Museum of Folk Architecture and Customs in Uzhhorod, SHEE Uzhhorod National University's Department of Archeology, Ethnology and Cultural Studies. Uzhhorod: Oleksandra Harkusha Publishing House, 2017, iss. 2, pp. 56-62 [in Ukrainian].

64. KHOTKEVYCH, Hnat. Hutsuls and Hutsulshchyna. New York: Freedom, 1920, 32 pp. [in Ukrainian].

65. CHIKH-KNYSH, Bohdana. Local Artistic Features of Hutsul Keptari. In: Vasyl GRESHCHUK (editorial board's chair). Bulletin of the Precarpathian University. Art Studies Series. Institute of Culture and Arts of the Vasyl Stefanyk Precarpathian National University. IvanoFrankivsk: Play, 2003, iss. V, pp. 162-169 [in Ukrainian].

66. KOŽMínOVÁ. Amalie. Podkarpatská Rus. Práce a život lidu po stránce kulturní, hospodářské a národopisné [Subcarpathian Rus. Work and Life of the People in Terms of Culture, Economics, and Ethnography]. Prague, 1922, 124 pp. [in Czech]. 